\title{
Gold(I)-selenolate complexes: Synthesis, characterization and ligand exchange reactions
}

\author{
KRISHNA P BHABAK and GOVINDASAMY MUGESH* \\ Department of Inorganic and Physical Chemistry, Indian Institute of Science, Bangalore 560012, India \\ e-mail: mugesh@ipc.iisc.ernet.in
}

\begin{abstract}
In this paper, the synthesis and characterization of some imidazole-based gold-selenolates are described. This study indicates that the nature of selenolate plays an important role in ligand exchange reactions in gold(I) selenolates. Furthermore, the reactivity of imidazole-based gold(I) selenolates toward nucleophiles such as selenols and phosphines is strikingly different from that of the $N, N$-dimethylaminobenzylamine-based gold(I) complexes. The presence of Se $\cdots \mathrm{N}$ non-bonded interactions in $N, N$-dimethylaminobenzylamine-based gold(I) complexes modulates the reactivity of $\mathrm{Au}(\mathrm{I})$ centre towards incoming nucleophiles.
\end{abstract}

Keywords. Ligand exchange; gold; phosphines; selenium; selenoenzymes.

\section{Introduction}

Gold(I) complexes such as auranofin (1, AUR), gold thioglucose (2, GTG) and gold thiomalate (3, GTM) (figure 1) have been used as therapeutic drugs for Rheumatoid Arthritis (RA) for a long period of time. ${ }^{1}$ The biochemical mechanism for the action of these compounds in RA is complex as these compounds interact with several biomolecules. Owing to the higher affinity of gold(I) towards sulfur and selenium, gold(I) drugs rapidly react with activated cysteine or selenocysteine residues of enzymes to form protein-gold(I)thiolate or protein-gold(I)-selenolate complexes. ${ }^{2}$ It is known that the gold(I) drugs rapidly bind to the most abundant plasma protein serum albumin (Alb-SH) after their administration, which is important for the transport of these drugs. ${ }^{3}$ The interaction of AUR with Alb$\mathrm{SH}$ has been studied extensively in recent years and these studies reveal that AUR reacts with the active site cysteine residue (Cys-34) of Alb-SH to produce the corresponding albumin-gold(I)-phosphine (Alb-S$\mathrm{Au}-\mathrm{PEt}_{3}$ ) complex. ${ }^{3}$

Similarly, the gold-phosphole complex $\mathbf{4}$ has been shown to react with the Cys-284 of human glutathione reductase (hGR) to produce a stable protein-gold(I)phosphole (Cys284-S-Au-phosphole) complex. ${ }^{4}$ Interestingly, gold(I) drugs effectively inhibit several seleno-

\footnotetext{
${ }^{*}$ For correspondence
}

enzymes such as glutathione peroxidase (GPx), ${ }^{5}$ thioredoxin reductase (TrxR $)^{6}$ and iodothyronine deiodinase (ID-1), ${ }^{7}$ by forming gold(I)-selenolate complexes with the selenocysteine $(\mathrm{Sec})$ residues at the active sites. The formation of gold(I)-selenolate complexes in proteins appears to be more facile than the formation of gold(I)thiolates. For example, the substitution of Sec in ID-1 by a Cys residue significantly reduced the sensitivity of the enzyme toward GTG. ${ }^{7}$ Recently, we have shown that trialkyl/aryl gold(I) chlorides $\left(\mathrm{R}_{3} \mathrm{PAuCl}, \mathrm{R}=\mathrm{Me}\right.$, Et or $\mathrm{Ph}$ ) inhibit the GPx activity of the selenol $\mathbf{5}$ by forming gold(I)-selenolate complexes (6-8) ${ }^{8}$ Gimeno and co-workers reported similar gold-selenolates (9-10) bearing the $N, N$-dimethylbenzylamine moiety (figure 2). ${ }^{9}$

It has been reported that the amino group in $\mathbf{5}$ plays an important role in the GPx activity as the Se... N non-covalent interactions in the key catalytic intermediates modulate the catalytic activity. ${ }^{8,10}$ In the natural GPx enzyme, two amino acid residues, glutamine (Gln) and tryptophan (Trp), form a 'catalytic triad' with the Sec residue at the active site. ${ }^{11}$ In ID-1 and TrxR, histidine residues (His) have been shown to play crucial roles in the catalysis. ${ }^{12}$ However, it is not known whether these proximal amino acid residues modulate the reactivity or stability of the gold-selenolate complexes during inhibition by gold(I) complexes. In this paper, we describe, for the first time, the mode of ligand exchange reactions at $\mathrm{Au}(\mathrm{I})$ center in goldselenolates in the presence or absence of any Se $\cdots \mathrm{N}$ interactions. 


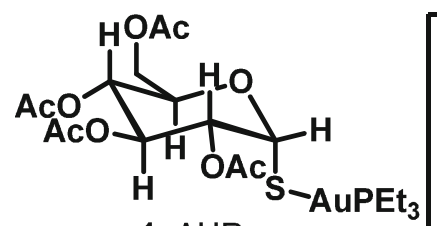

1, AUR<smiles>CC(C)(C)[AlH2]SC(CC(=O)O[Na])C(=O)O[Na]</smiles>

3, GTM
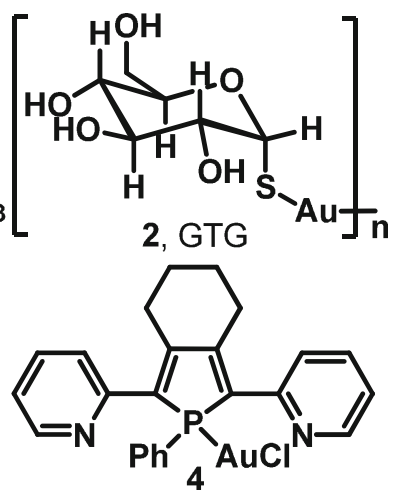

Figure 1. Chemical structures of therapeutic gold(I) compounds 1-4.

\section{Experimental}

\subsection{General procedure}

Trimethylphosphine gold(I) chloride, triethylphosphine gold(I) chloride, triphenylphosphine gold(I) chloride and sodium borohydride were purchased from SigmaAldrich. The experiments were carried out under dry and oxygen-free nitrogen using standard Schlenk techniques for the synthesis. ${ }^{1} \mathrm{H}(400 \mathrm{MHz}),{ }^{13} \mathrm{C}(100 \mathrm{MHz})$, ${ }^{31} \mathrm{P}(162 \mathrm{MHz})$ and ${ }^{77} \mathrm{Se}(76 \mathrm{MHz}) \mathrm{NMR}$ spectra were obtained on a Bruker $400 \mathrm{MHz}$ NMR spectrometer. Chemical shifts are cited with respect to $\mathrm{Me}_{4} \mathrm{Si}$ as internal $\left({ }^{1} \mathrm{H}\right.$ and $\left.{ }^{13} \mathrm{C}\right), \mathrm{H}_{3} \mathrm{PO}_{4}\left({ }^{31} \mathrm{P}\right)$ and $\mathrm{Me}_{2} \mathrm{Se}$ as external $\left({ }^{77} \mathrm{Se}\right)$ standards. Mass spectral studies were carried out on a Bruker Daltonics Esquire 6000plus mass spectrometer with ESI-MS mode analysis. The diselenide $\mathbf{1 1}$ was synthesized following the literature method. ${ }^{13 a}$

\subsection{Synthesis of gold-selenolates 13-15}

To a deoxygenated aqueous solution of the diselenide 11 (30.0 mg, $0.094 \mathrm{mmol})$ was added sodium

borohydride $(35.0 \mathrm{mg}, 0.940 \mathrm{mmol})$ to generate the corresponding selenol 12. The resulting selenol was extracted with deoxygenated chloroform and then the appropriate phosphine gold(I) chloride $(0.094 \mathrm{mmol})$ was added. The reaction mixture was stirred at room temperature for $1 \mathrm{~h}$. The solvent was evaporated in vacuo. The gold(I) selenolates 13-15 were obtained as yellow semi-solid products in almost quantitative yields. 2.2a Compound 13: ${ }^{1} \mathrm{H}$ NMR $\left(\mathrm{CDCl}_{3}\right) \delta(\mathrm{ppm})$ : $1.66-1.69(\mathrm{~d}, J=12.0 \mathrm{~Hz}, 9 \mathrm{H}), 3.63(\mathrm{~s}, 3 \mathrm{H}), 6.94$ (s, 1H), 7.09 (s, 1H). ${ }^{13} \mathrm{C} \mathrm{NMR}\left(\mathrm{CDCl}_{3}\right) \delta(\mathrm{ppm}): 14.9$ $\left(\mathrm{d}, J_{\mathrm{C}-\mathrm{P}}=37.0 \mathrm{~Hz}\right), 35.1,118.1,121.0,139.9 .{ }^{31} \mathrm{P} \mathrm{NMR}$ $\left(\mathrm{CDCl}_{3}\right) \delta(\mathrm{ppm}):-0.6 .{ }^{77} \mathrm{Se} \mathrm{NMR}\left(\mathrm{CDCl}_{3}\right) \delta(\mathrm{ppm})$ : 34. ESI-MS $m / z$ calcd. for $\mathrm{C}_{7} \mathrm{H}_{14} \mathrm{~N}_{2}$ AuPSe $[\mathrm{M}+\mathrm{H}]^{+}$ 434.9; found 434.8 .

2.2b Compound 14: ${ }^{1} \mathrm{H}$ NMR $\left(\mathrm{CDCl}_{3}\right) \delta(\mathrm{ppm})$ : 1.10-1.19 (m, 9H), $1.91(\mathrm{~m}, 6 \mathrm{H}), 3.64(\mathrm{~s}, 3 \mathrm{H})$, $6.97(\mathrm{~d}, J=2.0 \mathrm{~Hz}, 1 \mathrm{H}), 7.09(\mathrm{~d}, J=2.0 \mathrm{~Hz}$, 1H). ${ }^{13} \mathrm{C} \mathrm{NMR}\left(\mathrm{CDCl}_{3}\right) \delta(\mathrm{ppm}): 9.4,17.9\left(\mathrm{~d}, J_{\mathrm{C}-\mathrm{P}}=\right.$ $34.0 \mathrm{~Hz}), 36.6,119.7,122.5,141.0 .{ }^{31} \mathrm{P} \mathrm{NMR}\left(\mathrm{CDCl}_{3}\right)$ $\delta$ (ppm): $36.1{ }^{77} \mathrm{Se} \mathrm{NMR}\left(\mathrm{CDCl}_{3}\right) \delta(\mathrm{ppm}): 46$. ESI-MS $m / z$ calcd. for $\mathrm{C}_{10} \mathrm{H}_{20} \mathrm{~N}_{2} \mathrm{AuPSe}[\mathrm{M}+\mathrm{H}]^{+} 477.0$; found 477.0.

2.2c Compound 15: ${ }^{1} \mathrm{H}$ NMR $\left(\mathrm{CDCl}_{3}\right) \delta(\mathrm{ppm})$ : $3.68(\mathrm{~s}, 3 \mathrm{H}), 6.88(\mathrm{~s}, 1 \mathrm{H}), 7.10(\mathrm{~s}, 1 \mathrm{H}), 7.42-7.49$ $(\mathrm{m}, 10 \mathrm{H}), 7.57-7.63(\mathrm{~m}, 5 \mathrm{H}) .{ }^{13} \mathrm{C}$ NMR $\left(\mathrm{CDCl}_{3}\right) \delta$ (ppm): $36.6,119.5,121.9,129.5\left(\mathrm{~d}, J_{\mathrm{C}-\mathrm{P}}=11.0 \mathrm{~Hz}\right)$, $130.0,130.7,131.9,134.7\left(\mathrm{~d}, J_{\mathrm{C}-\mathrm{P}}=13.0 \mathrm{~Hz}\right)$, 143.7, 143.9. ${ }^{31} \mathrm{P}$ NMR $\left(\mathrm{CDCl}_{3}\right) \delta$ (ppm): $35.6 .{ }^{77} \mathrm{Se}$ NMR $\left(\mathrm{CDCl}_{3}\right) \delta$ (ppm): 22. ESI-MS $\mathrm{m} / z$ calcd. for $\mathrm{C}_{22} \mathrm{H}_{20} \mathrm{~N}_{2}$ AuPSe $[\mathrm{M}+\mathrm{H}]^{+}$621.0; found 620.9.

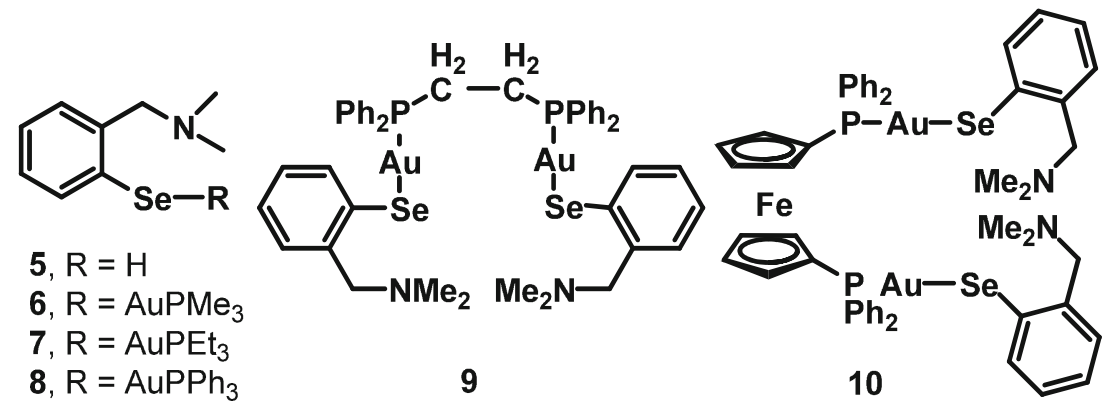

Figure 2. Chemical structures of selenol 5 and gold(I)-selenolate complexes 6-10. 


\subsection{General procedure for the reaction of gold- selenolates with selenolate and phosphines}

The reactions of gold-selenolates $\mathbf{1 3 - 1 5}$ with selenolate 12 and triphenylphosphine $\left(\mathrm{PPh}_{3}\right)$ were carried out in NMR tube using $\mathrm{MeOH}$ as solvent. To a methanolic solution of complexes 13-15, was added required amount of either selenolate $\mathbf{1 2}$ (freshly prepared by the reduction of the corresponding diselenide 11) or $\mathrm{PPh}_{3}$. The resultant solution was mixed thoroughly and then studied by ${ }^{77} \mathrm{Se},{ }^{31} \mathrm{P}$ NMR and ESI-MS techniques to understand the ligand exchange reactions and to analyse the final products.

\section{$2.4 \quad X$-ray crystallography}

Single crystal X-ray diffraction data was collected on a Bruker AXS SMART APEX CCD diffractometer at room temperature $(291 \mathrm{~K})$. The $\mathrm{X}$-ray generator was operated at $50 \mathrm{KV}$ and $35 \mathrm{~mA}$ using $\mathrm{Mo}-\mathrm{K} \alpha$ radiation $(\lambda=0.71073 \AA)$. The data was collected using SMART software package. ${ }^{14}$ The data were reduced by SAINTPLUS, ${ }^{14}$ an empirical absorption correction was applied using the package SADABS ${ }^{15}$ and XPREP ${ }^{14}$ was used to determine the space group. The crystal structure was solved by direct methods using SIR $92^{16}$ and refined by full-matrix least-squares method using SHELXL97. ${ }^{17}$ All non-hydrogen atoms were refined anisotropically and hydrogen atoms were assigned at idealized locations.

2.4a Crystal data for compound $13:{ }^{18} \mathrm{C}_{7} \mathrm{H}_{15} \mathrm{~N}_{2} \mathrm{PSeAuCl}$; $M_{r}=469.5$; monoclinic; space group: $P 21 / \mathrm{c} ; a=$ 11.8096(28) $\AA$; $b=26.4283(61) \AA ; c=11.5510(27)$ $\AA ; \alpha=90.00(0)^{\circ} ; \beta=113.270(4)^{\circ} ; \gamma=90.000(0)^{\circ}$; $V=3311.89(63) \AA^{3} ; \rho_{\text {calc }}=1.88 \mathrm{~g} \mathrm{~m}^{-3} ; Z=8$; $\operatorname{MoK}_{\alpha}$ radiation $(\lambda=0.71370 \AA) ; T=291(2) \mathrm{K} ; R_{\text {int }}$ : $0.054 ; R$ (observed data): $R_{1}=0.061 ; w R_{2}=0.105$; $R$ (all data): $R_{1}=0.043 ; w R_{2}=0.099 ; \mathrm{GOF}=0.929 ;$ $\Delta \rho_{\min }$ and $\Delta \rho_{\max }\left(\mathrm{e}^{-3}\right):-1.733$ and 2.010 .

\section{Results and discussion}

\subsection{Synthesis of gold(I)-selenolates}

The imidazole-based gold-selenolates 13-15 were synthesized by treating $\mathrm{R}_{3} \mathrm{PAuCl}(\mathrm{R}=\mathrm{Me}$, Et or $\mathrm{Ph})$ with the selenolate $\mathbf{1 2}$ (scheme 1). The diselenide $\mathbf{1 1}$ can be quantitatively reduced to the corresponding selenol 12 by the treatment of $\mathrm{NaBH}_{4} .{ }^{13}$ The selenol produced in this reaction exists predominantly in its zwitterionic form (2B) having a large negative charge on selenium atom as shown in scheme 1. A nucleophilic attack of the selenol 12 at the $\mathrm{Au}(\mathrm{I})$ centre of $\mathrm{R}_{3} \mathrm{PAuCl}$ produces the corresponding gold-selenolates 13-15 almost in quantitative yields. All the gold-selenolates were characterized by NMR $\left({ }^{1} \mathrm{H},{ }^{13} \mathrm{C},{ }^{31} \mathrm{P}\right.$ and $\left.{ }^{77} \mathrm{Se}\right)$ spectroscopic and ESI-MS spectrometric techniques.

\subsection{Structural features of gold(I)-selenolate $\mathbf{1 3}$}

To understand the important structural features in the gold-selenolates, complex $\mathbf{1 3}$ was studied by single crystal X-ray diffraction. After the synthesis of complex 13 in chloroform, the crude compound was recrystallized from chloroform/methanol (1:1) mixture to afford faint yellowish needle-shaped crystals. As shown in figure 3, the structure of complex $\mathbf{1 3}$ was found to be dimeric with a weak $\mathrm{Au} \cdot \mathrm{Au}$ Aun-covalent aurophilic interaction (dAu1 $\cdots A$ Au2 $=3.104 \AA)$, which was much shorter than the sum of van der Waals radii of Au atoms (3.40 ̊).

As expected, an almost linear arrangement of $\mathrm{Se}-$ $\mathrm{Au}-\mathrm{P}$ moieties were observed ( $\theta$ Se1-Au1-P1: $175.9^{\circ}$ and $\theta \mathrm{Se} 2-\mathrm{Au} 2-\mathrm{P} 2: 172.4^{\circ}$ ), which is a characteristic of $\mathrm{Au}(\mathrm{I})$ complexes. ${ }^{4,9}$ A small deviation from the linearity is probably due to the presence of $\mathrm{Au} \cdots \mathrm{Au}$ aurophilic interaction. Similar structural features were also observed for complexes $\mathbf{9}$ and $\mathbf{1 0}$ as reported by Gimeno and co-workers. ${ }^{9}$ While the $\mathrm{Au}$.. Au distance of $3.104 \AA$ in complex $\mathbf{1 3}$ is comparable to that of $\mathbf{9}$ (3.091 $\AA$ ), the distance is found to be slightly longer

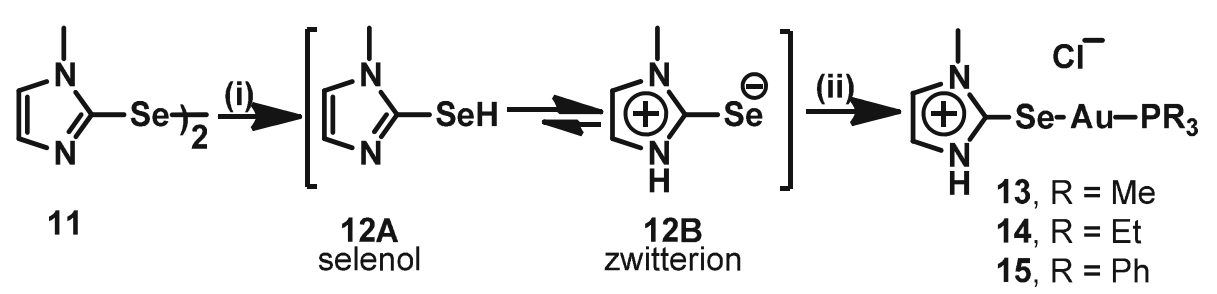

Scheme 1. Synthetic routes to the gold-selenolates (13-15). (i) $\mathrm{NaBH}_{4}, \mathrm{CHCl}_{3}$ / $\mathrm{H}_{2} \mathrm{O}$; (ii) $\mathrm{R}_{3} \mathrm{PAuCl}(\mathrm{R}=\mathrm{Me}$, Et or $\mathrm{Ph}), \mathrm{CHCl}_{3}$. 


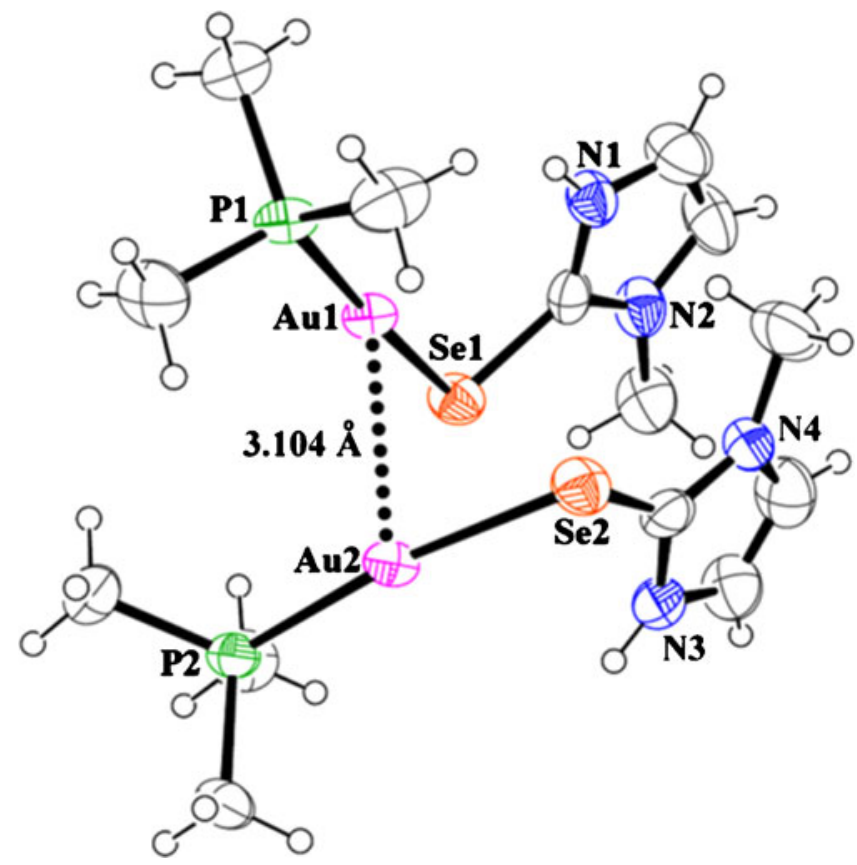

Figure 3. X-ray crystal structure of gold-selenolate complex 13. Displacement ellipsoids are drawn at $50 \%$ probability level and hydrogen atoms are shown as small spheres of arbitrary radii. Two chloride counterions $\left(\mathrm{Cl}^{-}\right)$in the molecule are omitted for the structural clarity.

than that reported for complex $\mathbf{1 0}(3.024 \AA)$. Although two $\mathrm{Cl}^{-}$counterions were present in the crystal structure of complex 13 , both of the $\mathrm{Cl}^{-}$ions were far away from the $\mathrm{Au}$ and $\mathrm{Se}$ centres. Furthermore, both the $\mathrm{Cl}^{-}$ions were located nearer to one imidazole-goldselenolate unit. For example, the distance of $\mathrm{Cl}^{-}$ions from $\mathrm{Au} 2$ and $\mathrm{Se} 2$ are found to be much higher than the distance from Au1 and Se1 centres. However, all these distances are much higher than the sum of van der Waals distance of $\mathrm{Se} / \mathrm{Au}$ and $\mathrm{Cl}$ atoms indicating the absence of any non-bonded interactions (table 1).

\subsection{Ligand exchange reactions in gold(I)-selenolates}

It has been shown that ligand exchange reactions play an important role in the inhibition of GPx. ${ }^{5}$ For example, GTG undergoes ligand displacement reactions with glutathione $(\mathrm{GSH})$ to produce $\left[\mathrm{Au}(\mathrm{SG})_{2}\right]^{-}$complex, which is probably responsible for the inhibition of the enzyme.$^{5 \mathrm{c}}$ The synthetic gold-selenolate complexes 6-8 also undergo extensive ligand exchange reactions in the presence of selenol 5 and phosphines. ${ }^{8}$ In these reactions, the trialkyl/aryl phosphines were eliminated, which underwent further reactions with oxygen and selenium powder to produce the corresponding phosphine oxides $\left(\mathrm{R}_{3} \mathrm{P}=\mathrm{O}\right)$ and selenides $\left(\mathrm{R}_{3} \mathrm{P}=\mathrm{Se}\right){ }^{8}$ In contrast, reactions of the imidazole-based selenol 12 with trialkyl/aryl gold chlorides produced the corresponding gold-selenolates (13-15) and the formation of phosphine oxides or selenides was not observed. These observations indicate that the $\mathrm{Se} \cdots \mathrm{N}$ interactions in complexes 6-8 may activate the $\mathrm{S}-\mathrm{Au}$ and $\mathrm{Au}-\mathrm{P}$ bonds toward ligand displacement reactions. When complex 6 was treated with $\mathbf{5}$, the formation of bis-selenolate-gold complex 16 was observed due to the replacement of the phosphine ligand by the selenol (scheme 2). ${ }^{8}$ In contrast, no such reaction was observed when complex $\mathbf{1 4}$ was treated with an equimolar amount of compound $\mathbf{1 2}$. Although a small amount of triethyl phosphine oxide $\left(\mathrm{Et}_{3} \mathrm{P}=\mathrm{O}\right)$ was observed in the reaction, the ESI-MS spectrum indicated that the selenolate and phosphine ligands are intact in complex 14 (figures S13 and S14 of Supporting Information). These observations indicate that the notable differences in reactivity of complexes 6-8 and $\mathbf{1 4}$ towards corresponding selenols are probably due to the differences in nucleophilicity/basicity of $-\mathrm{NMe}_{2}$ and $\mathrm{Cl}^{-}$moieties.

A striking difference in the reactivity of these two types of gold-selenolates toward selenols prompted us to investigate the phosphine exchange reactions. As

Table 1. Some important bond distances, bond angles and non-bonding distances in the crystal structure of complex $\mathbf{1 3 .}$

\begin{tabular}{|c|c|c|c|c|c|}
\hline Au1-Se1 & $2.440(1)$ & $\mathrm{Au} 2-\mathrm{Au} 1-\mathrm{Se} 1$ & $83.33(3)$ & $\mathrm{Au} 1 \cdots \cdot \mathrm{Au} 2$ & 3.104 \\
\hline Au1-P1 & $2.267(2)$ & $\mathrm{Au} 2-\mathrm{Au} 1-\mathrm{P} 1$ & $102.72(6)$ & Se1 $\ldots$ Cl1 & 4.926 \\
\hline $\mathrm{Au} 2-\mathrm{Se} 2$ & $2.4396(9)$ & Se1-Au1-P1 & $172.41(7)$ & $\mathrm{Se} 1 \cdots \mathrm{Cl} 2$ & 8.988 \\
\hline Au2-P2 & $2.266(2)$ & $\mathrm{Au} 1-\mathrm{Au} 2-\mathrm{Se} 2$ & $86.89(2)$ & $\mathrm{Au} 1 \ldots \mathrm{Cl} 1$ & 3.947 \\
\hline $\mathrm{Se} 2-\mathrm{C} 8$ & 1.882(9) & $\mathrm{Au} 1-\mathrm{Au} 2-\mathrm{P} 2$ & $96.97(6)$ & $\mathrm{Au} 1 \cdots \mathrm{Cl} 2$ & 6.620 \\
\hline Se1-C1 & $1.89(1)$ & $\mathrm{Se} 2-\mathrm{Au} 2-\mathrm{P} 2$ & $175.98(7)$ & $\mathrm{P} 1 \ldots \mathrm{Cl} 1$ & 4.002 \\
\hline P1-C6 & 1.79(1) & $\mathrm{Au} 2-\mathrm{Se} 2-\mathrm{C} 8$ & 101.1(3) & $\mathrm{P} 1 \ldots \mathrm{Cl} 2$ & 4.441 \\
\hline P1-C5 & $1.80(1)$ & Au1-Se1-C1 & $96.8(3)$ & $\mathrm{Se} 1 \cdots \mathrm{Au} 2$ & 3.719 \\
\hline $\mathrm{P} 1-\mathrm{C} 7$ & $1.79(1)$ & Au1-P1-C6 & $110.5(4)$ & Se2...Au 1 & 3.842 \\
\hline $\mathrm{P} 2-\mathrm{C} 13$ & $1.83(1)$ & Au1-P1-C5 & $112.8(4)$ & N1H1 ...Cl1 & 2.298 \\
\hline P2-C12 & $1.82(1)$ & Au1-P1-C7 & $116.5(4)$ & $\mathrm{N} 1 \cdots \mathrm{Cl} 1$ & 3.109 \\
\hline
\end{tabular}




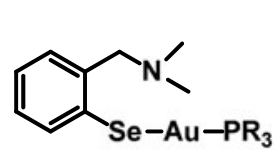

6, $\mathrm{R}=\mathrm{Me} ; 7, \mathrm{R}=\mathrm{Et}$ $8, \mathrm{R}=\mathrm{Ph}$

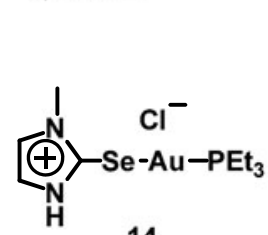

14

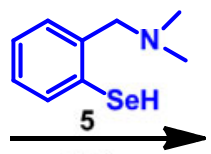

$-\mathrm{PR}_{3}$

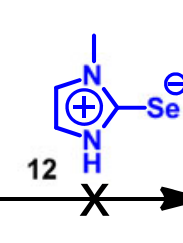<smiles>Cc1ccccc1CN(C)C</smiles>

16

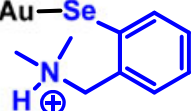

Scheme 2. Nucleophilic attack of the selenol $\mathbf{5}$ at the $\mathrm{Au}(\mathrm{I})$-centre in gold-selenolates $\mathbf{6}-\mathbf{8}$ produces the bisselenolate-gold complex 16. No such reaction was observed when the selenolate $\mathbf{1 2}$ was added to complex $\mathbf{1 4}$.

shown previously, addition of $\mathrm{PPh}_{3}$ to the benzylaminebased gold-selenolate complexes 6-7 leads to a rapid elimination of $\mathrm{PMe}_{3}$ or $\mathrm{PEt}_{3}$ to produce complex 8. ${ }^{8}$ In contrast, the imidazole-based gold-selenolates 13-14 do not undergo any phosphine displacement reactions in the presence of $\mathrm{PPh}_{3}$. For example, the treatment of $\mathbf{1 4}$ with an excess amount $(\sim 5$ equiv) of $\mathrm{PPh}_{3}$ does not produce the phosphine-exchanged product 15. Interestingly, the ${ }^{31} \mathrm{P}$ NMR spectroscopic and ESI-MS spectrometric analyses revealed the formation of $\left[\mathrm{Et}_{3} \mathrm{PAuPPh}_{3}\right]^{+}$species, indicating that the addition of $\mathrm{PPh}_{3}$ led to the elimination of the selenolate ligand. The $\left[\mathrm{Et}_{3} \mathrm{PAuPPh}_{3}\right]^{+}$species produced in the reaction reacts with $\mathrm{PPh}_{3}$ to produce $\left[\left(\mathrm{PPh}_{3}\right)_{2} \mathrm{Au}\right]^{+}$cation by phosphine exchange reactions (scheme 3 ). Furthermore, the produced cationic gold-phosphine complexes such as $\left[\mathrm{Et}_{3} \mathrm{PAuPPh}_{3}\right]^{+}$and $\left[\left(\mathrm{PPh}_{3}\right)_{2} \mathrm{Au}\right]^{+}$may undergo a charge balance with $\mathrm{Cl}^{-}$counterions as shown in scheme 3. As expected, a line broadening in ${ }^{31} \mathrm{P}$ NMR signal was observed during the course of phosphine exchange reactions. Although there is no direct evidence, the elimination of selenolate in the reaction of $\mathbf{1 4}$ with $\mathrm{PPh}_{3}$ is probably due to the stronger trans effect of the phosphine ligand as compared to the selenolate ligand, which leads to the weakening of the $\mathrm{Au}-\mathrm{Se}$ bond. Whereas, the Se...N interactions in the benzylaminebased gold-selenolates 6-8 may reduce the trans directing effect of phosphine group, leading to the weakening of the $\mathrm{Au}-\mathrm{P}$ bonds. This may facilitate the phosphine exchange reactions as shown in scheme 3 . These observations lead to the assumption that the nonbonded interactions at the selenium centres in goldselenolates may modulate the ligand exchange reactions at the $\mathrm{Au}(\mathrm{I})$ centres.
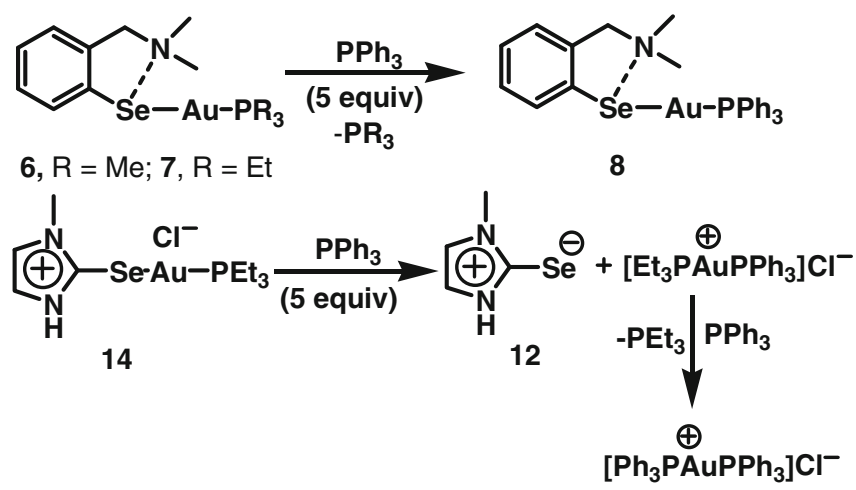

Scheme 3. Differences in the reactivity of complexes $\mathbf{6}$, 7 and $\mathbf{1 4}$ towards $\mathrm{PPh}_{3}$.

\subsection{Possible pathways of different ligand exchange reactions}

Coffer et al. have previously shown that the nucleophilic attack of the Cys-34 residue of albumin at the $\mathrm{Au}(\mathrm{I})$ centre of AUR leads to the formation of proteingold-phosphine (Alb-S-AuPEt ${ }_{3}$ ) complex, indicating that the replacement of thioglucose moiety is more favoured than that of the $\mathrm{PEt}_{3}$ ligand. ${ }^{3 a}$ However, it is not clear whether the elimination of gold(I)-phosphine moiety from an enzyme active site alters the inhibition property of the gold(I) complexes. The present study indicates that the nature of selenolate can alter the ligand exchange reactions at the gold(I) centre. This study also suggests that the effect of gold(I) drugs on selenoenzymes not only depends on the reactivity of Sec toward these gold(I) complexes, but also the stability of $\mathrm{Se}-\mathrm{Au}$ bond in the enzyme-bound complex. For example, the presence of a ligand (L) in biological medium may have different effects on the gold(I)selenocysteine complexes as shown in scheme 4 . In the first scenario, the addition of L does not lead to any ligand displacement reactions. In such case, the enzyme activity is expected to be strongly inhibited by the treatment of enzyme with gold(I) complexes such as AUR. In the second pathway, the replacement of phosphine ligand by L may not affect the inhibition as the Sec residue is still bonded to the gold(I) moiety. In contrast, a recovery of enzyme activity is expected when the ligand $\mathrm{L}$ attacks at the $\mathrm{Au}(\mathrm{I})$ centre to release the catalytically active selenol (scheme 4). Therefore, the ligand exchange reactions at the $\mathrm{Au}(\mathrm{I})$ centres in proteingold complexes may or may not affect the inhibition of enzymatic activity depending on the relative strength of protein(Sec)-gold and gold-phosphine bonds. Furthermore, this scheme indicates that, for an effective 


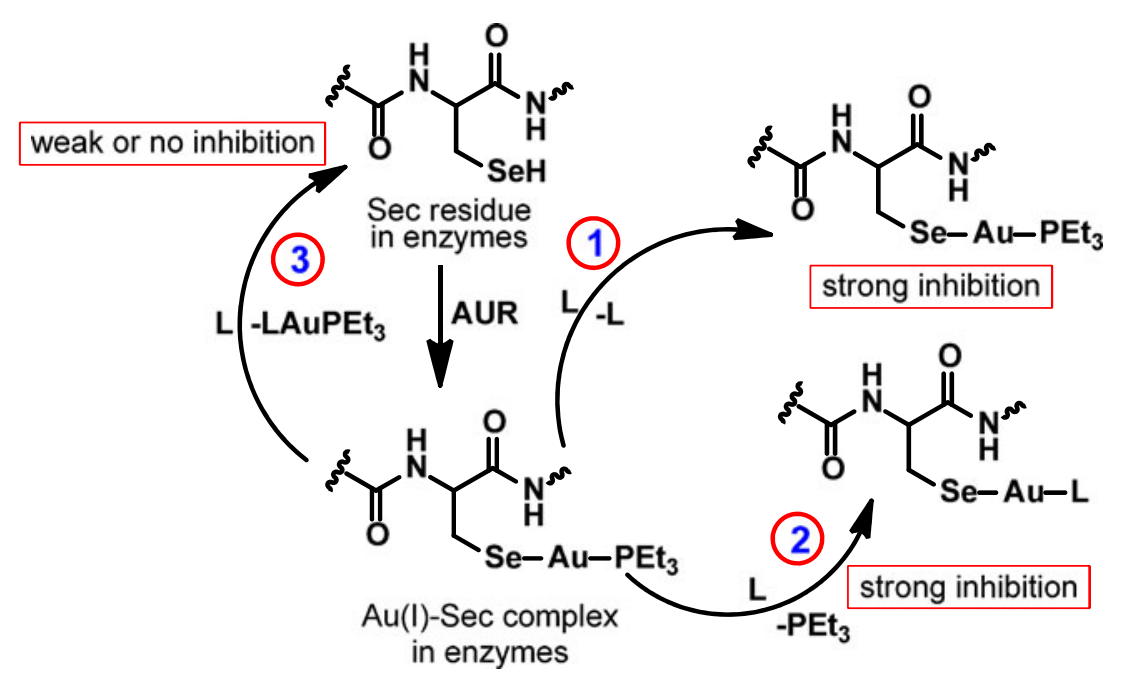

Scheme 4. Schematic representation of different ligand exchange reaction pathways in gold(I)-selenocysteine complexes in enzymes.

inhibition of selenoenzymes by gold(I) drugs, the $\mathrm{Se}-$ $\mathrm{Au}$ bond should be more stable than that of the $\mathrm{Au}-\mathrm{P}$ bonds.

\section{Conclusion}

In summary, some imidazole-based gold(I)-selenolates have been synthesized, characterized and studied for their reactivity towards different nucleophiles. This study indicates that the nature of selenolate plays an important role in ligand exchange reactions in gold-selenolates. The reactivity of the imidazolebased gold(I)-selenolates toward selenols and phosphines is significantly different from that of the $N, N$ dimethylbenzylamine-based gold(I) complexes. The strong trans effect of phosphines probably makes the $\mathrm{Au}(\mathrm{I})-\mathrm{Se}$ bond relatively weaker, leading to the cleavage of $\mathrm{Au}(\mathrm{I})-\mathrm{Se}$ bond in $\operatorname{gold}(\mathrm{I})-$ selenolates upon the nucleophilic attack of selenols and phosphines. These observations suggest that the effect of gold(I) drugs on selenoenzymes may not only depend on the reactivity of Sec toward these gold(I) complexes, but also on the stability of Se-Au bond in the gold(I)-selenolate complex of the enzyme.

\section{Supporting information}

NMR and ESI-MS spectral data of all the goldselenolate complexes are given in supplementary information (figures S1-S18). Supplementary data to this article can be found in the Website www.ias.ac. in/chemsci.

\section{Acknowledgements}

This study was supported by the Department of Science and Technology (DST), New Delhi, India. GM acknowledges the DST for the Swarnajayanti fellowship and KPB thanks Indian Institute of Science, Bangalore for a Research Associate fellowship.

\section{References}

1. a) Brown D H and Smith W E 1980 Chem. Soc. Rev. 9 217. b) Fricker S P 1996 Gold Bull. 2953 c) Shaw III C F 1999 Chem. Rev. 99 2589. d) Tiekink E R T 2002 Critical Rev. Oncol./Hematol. 42 225. e) Molter A and Mohr F 2010 Coord. Chem. Rev. 25419

2. Bhabak K P, Bhuyan B J and Mugesh G 2011 Dalton Trans. 402099

3. a) Kinsch E M and Stephan D W 1984 Inorg. Chim. Acta 91 263. b) Coffer M T, Shaw III C F, Eidsness M K, Watkins II J W and Elder R C 1986 Inorg. Chem. 25333. c) Coffer M T, Shaw III C F, Hormann A L, Mirabelli C K and Crooke S T 1987 J. Inorg. Biochem. 30177. d) Shaw III C F, Isab A A, Hoeschele J D, Starich M, Locke J, Schulteis P and Xiao J 1994 J. Am. Chem. Soc. 116 2254. e) Hill D T, Isab A A, Griswold D E, DiMartino M J, Matz E D, Figueroa A L, Wawro J E, DeBrosse C, Reiff W M, Elder R C, Jones B, Webb J W and Shaw III C F 2010 Inorg. Chem. 497663

4. Urig S, Fritz-Wolf K, Réau R, Herold-Mende C, Tóth K, Davioud-Charvet E and Becker K 2006 Angew. Chem. Int. Ed. 451881

5. a) Chaudiere J and Tappel A L 1984 J. Inorg. Biochem. 20 313. b) Baker M A and Tappel A L 1986 Biochem. Pharmacol. 35 2417. c) Roberts J R and Shaw III C F 1998 Biochem. Pharmacol. 551291

6. a) Smith A D, Guidry C A, Morris V C and Levander O A 1998 J. Nutr. 129 194. b) Gromer S, Arscott L 
D, Williams C H Jr, Schirmer R H and Becker K 1998 J. Biol. Chem. 273 20096. c) Bindoli A, Rigobello M P, Scutari G, Gabbiani C, Casini A and Messori L 2009 Coord. Chem. Rev. 2531692

7. Berry M J, Kieffer J D, Harney J W and Larsen P R 1991 J. Biol. Chem. 26614155.

8. Bhabak K P and Mugesh G 2009 Inorg. Chem. 482449

9. Crespo O, Gimeno C, Laguna A, Kulcsar M and Silvestru C 2009 Inorg. Chem. 48

10. a) Mugesh G, Panda A, Singh H B, Punekar N S and Butcher R J 2001 J. Am. Chem. Soc. 123 839. b) Bhabak K P and Mugesh G 2008 Chem. Eur. J. 148640. c) Bhabak K P and Mugesh G 2009 Chem. Eur. J. 15 9846. d) Bhabak K P and Mugesh G 2010 Acc. Chem. Res. 431408

11. Ursini F, Maiorino M, Brigelius-Flohé R, Aumann K-D, Roveri A, Schomburg D and Flohé L 1995 Methods Enzymol. 25238

12. a) Mol J A, Docter R, Hennemann $G$ and Visser T J 1984 Biochem. Biophys. Res. Commun. 12028. b) Sandalova T, Zhong L, Lindqvist Y, Holmgren A and Schneider G 2001 Proc. Natl. Acad. Sci. USA 98 9533. c) Brandt W and Wessjohann L A 2005 Chem. Bio. Chem 6386

13. a) Roy G and Mugesh G 2005 J. Am. Chem. Soc. 127 15207. b) Roy G, Das D and Mugesh G 2007 Inorg. Chim. Acta 360303

14. Bruker. SMART (Version 6.028), SAINT (Version 6.02), XPREP. Bruker AXS Inc. Madison, Wisconsin, USA 1998

15. Sheldrick G M 1996 SADABS. University of Göttingen, Germany

16. Altomare A, Cascarano G, Giacovazzo C, Guagliardi A, Burla M C, Polidori G and Camalli M 1994 J. Appl. Crystalogr. 27435

17. Sheldrick G M 1997 SHELXS97 and SHELXL97. University of Göttingen, Germany

18. CCDC-828285 (13) contains the supplementary crystallographic data for this paper. These data can be obtained free of charge from The Cambridge Crystallographic Data Centre via www.ccdc.cam.ac.uk/data_ request/cif 